\title{
The Effect of Yield Strength on Side-'3onding Upset Welds
}

Roger G. Miller and Michael A. Perkins

September 24, 1991

\section{MOUND}

\section{operated by}

ELEG MOUND APPLIED TECHNOLOGIES

P.O. Box 3000. Miamisburg, Ohio 45343-3000

for the

U. S. DEPARTMENT OF ENERGY

Contract No. DE-AC04-88DP43495 


\section{DISCLAIMER}

This report was prepared as an account of work sponsored by an agency of the Unlted States Government. Nelther the Unlted States Government nor any agency thereof. nor any of their employees. makes any warranty. express or implied. or assumes any legal llability or responslbillty for the accuracy. completeness. or usefulness of any information. apparatus. product. or process disclosed. or represents that its use would not Infringe privately owned rights. Reference herein to any specific commercial product. process, or service by trade name, trademark. manufacturer. or otherwise. does not necessarlly constitute or imply its endorsement. recommendation. or favoring by the United States Government or any agency thereof. The views and opinions of authors expressed hereln do not necessarlly state or reflect those of the United States Government or any agency thereof.

This report has been reproduced directly from the best avallable copy.

Avallable to DOE and DOE contractors from:

Offlce of Sclentific and Technical Information

P.O. Box 62

Oak Ridge. TN 37831

Prices avallable from (615)576-8401. FTS 626-8401

Avallable to the public from:

National Technical Information Service

U.S. Department of Commerce

5285 Port Royal Rd.

Springfield. VA 22161 
MLM- -3705

DE92 001605

\title{
The Effect of Yield Strength on Side-Bonding Upset Welds
}

\author{
Roger G. Miller and Michael A. Perkins
}

Issued: September 24, 1991

\section{MOUND}

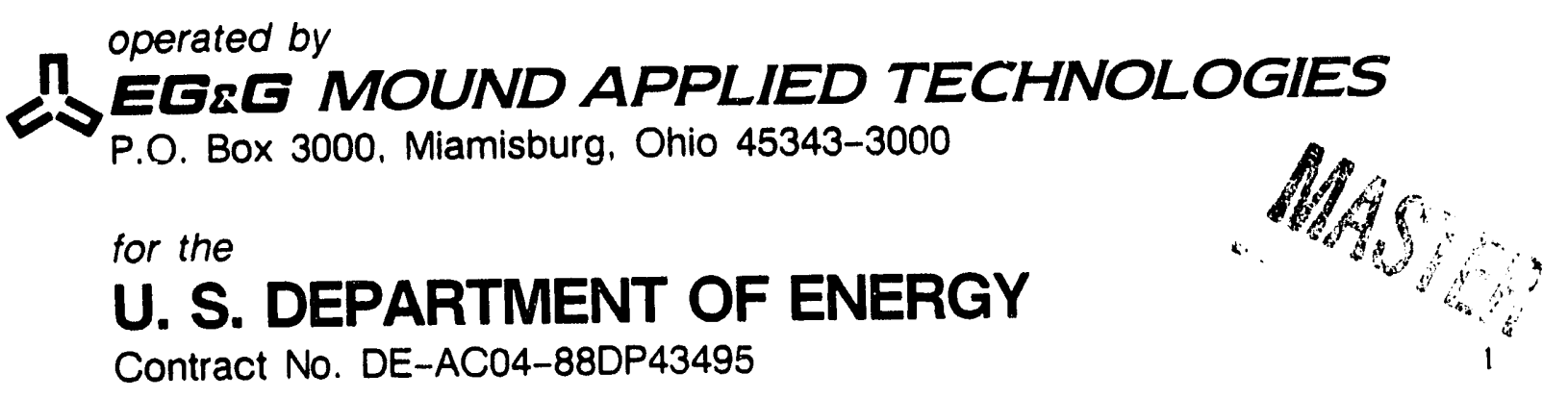




\section{Contents}

page

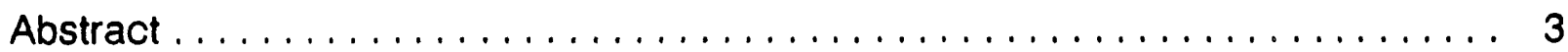

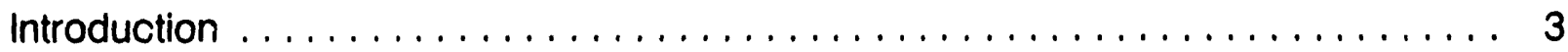

Upset Welding $\ldots \ldots \ldots \ldots \ldots \ldots \ldots \ldots \ldots \ldots \ldots \ldots \ldots \ldots \ldots \ldots \ldots$

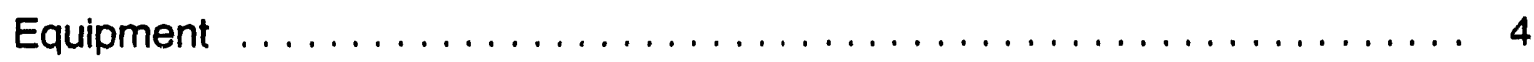

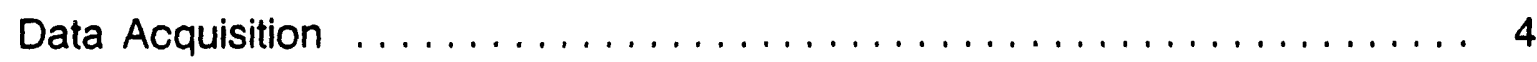

The 0.298 -in. Plug Upset Weld $\ldots \ldots \ldots \ldots \ldots \ldots \ldots \ldots \ldots \ldots \ldots \ldots \ldots$

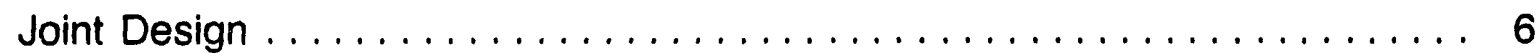

Welding Procedure $\ldots \ldots \ldots \ldots \ldots \ldots \ldots \ldots \ldots \ldots \ldots \ldots$

Experimental Work $\ldots \ldots \ldots \ldots \ldots \ldots \ldots \ldots \ldots \ldots \ldots \ldots$

Analysis of Data ............................... 10

The 0.440 -in. Stem Upset Weld $\ldots \ldots \ldots \ldots \ldots \ldots \ldots \ldots \ldots \ldots \ldots \ldots$

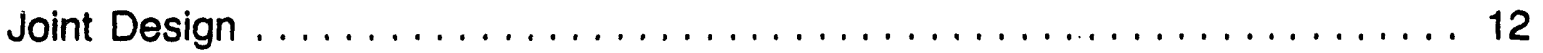

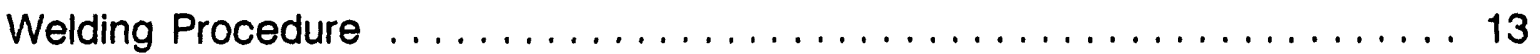

Experimental Work ............................ 13

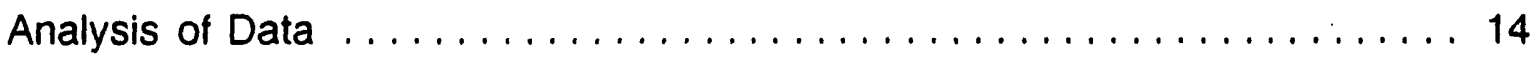

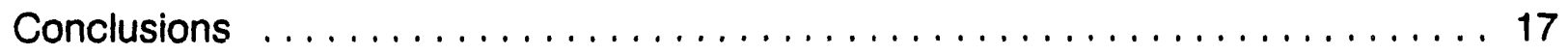

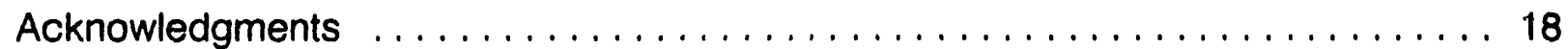

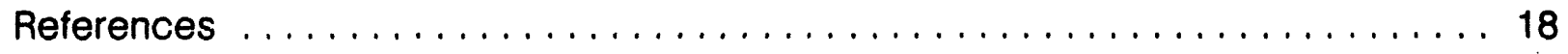

Appendix A: 0.298 -in. Plug Welding Data .................. 19

Appendix B: 0.440 -in. Stem Welding Data .................. 23

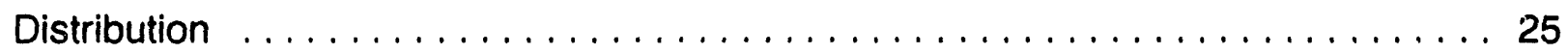




\begin{abstract}
During the course of $9^{\circ}$ tapered side-bonding resistance upset weld development at Mound, various studies have been conducted to evaluate the effect of yield strength on welds in $304 \mathrm{~L}$ stainless steel. The results of these studies have concluded that at high yield strengths there may be a minor reduction in the length of Class II or better bond. Satisfactory welds have been produced with materials having yield strengths ranging from 36.0 to $141.0 \mathrm{ksi}$. However, when body yield strengths exceed $80.0 \mathrm{ksi}$ a miryor decrease in bond lengths begins. A significant inverse relationship between stem yield strength and bond length was shown to exist.
\end{abstract}

\title{
Introduction
}

A side-bonding upset weld is a solid state bond produced at elevated temperatures and pressures. This process produces a solid state bond progressively along the weld joint by using resistance heating to recrystallize and grow plastically deformed grains across the welding interface. Since the bonding method does depend on the occurrence and degree of plastic deformation at the weld interface during the application of the welding force, it is easy to see where the yield strength of the parts being welded would be of paramount interest. As a result, two studies have been conducted to evaluate the effect of yield strength on side-bonding upset welds.

The joint designs developed at Mound incorporate a straight-sided flange welded into a $9^{\circ}$ tapered hole. This is a deviation from the more traditional straight-sided flange welded into a straight-sided hole. This change was made to increase the interference between the flange and the body at the root of the weld joint, thereby increasing the amount of work imparted to the body at the weld root and improving weld quality by increasing bond length. Other advantages of the tapered joint are lower welding force and heat input when compared to the equivalent straight sided joint. The disadvantage of the $9^{\circ}$ tapered joint is its increased sensitivity to cleanliness. With the tapered joint, cleanliness and its effect upon the coefficient of friction between the flange and the body are important and must be controlled. However. tapered joints are more accessible for cleaning and inspection than traditional straight sided weld joints.

Generally, the coefficient of friction is higher for cleaner surfaces. When the coefficient of friction is higher. more of the applied load is reacted directly by the frictional (shear) force. and less load is reacted by the normal force from the $9^{\circ}$ taper. Therefore, higher coefficients of friction result in lower stresses in the body for the same applied load. As a consequence, the higher shear forces produce more localized work in the weld joint, which is beneficial to weld quality. 
Because classical nondestructive testing techniques are of limited value with this solid state bonding process, all results in this report are based on the destructive evaluation of welds.

\section{Upset Welding}

\section{Equipment}

Upset welding was conducted on a system designed at Mound. Mound has eleven such upset welding systems in general use, for both development and production. While these systems have previously been described in detail [1], various modifications and improvements to the systems have been made. Foremost among the changes is the lise of a Druck pressure controller (Model No. DPI 500) on some welders to regulate the nitrogen supply to the single-action cylinder. Figure 1 is an updated schematic of the welder and data acquisition system used for upset welding at Mound.

All welding was conducted in boxlines with dry $\left(<10 \mathrm{ppm} \mathrm{O}_{2},<5 \mathrm{ppm} \mathrm{H}_{2} \mathrm{O}\right)$ argon atmospheres. Welding electrodes (Mound Drawing No. AYD871442, Detail 1 or AYC871622) composed of an RWMA (Resistance Welders Manufacturer's Association) Class 2 shaft with an RWMA Class 13 (tungsten) tip were used for all welding.

\section{Data Acquisition}

Upset welders are equipped with a data acquisition system capable of:

1. Recording the voltage waveform and calculating the RMS voltage.

2. Recording the current waveform and calculating the RMS current.

3. Recording the force waveform and calculating the mean force.

4. Recording the displacement waveform.

The system is also capable of taking and recording individual displacement readings and measuring the primary voltage befure welding. Several modifications have also been made to the upset welder data acquisition system. Foremost among those changes is the use of Hewlett-Packard computers (Models 220, 310, or 360). For those systems so equipped. the Hewlett-Packard computer is used to interface with the Pertron controller such that welding parameters are entered via the computer. The Hewlett-Packard computers are also used to control welding force by closed-loop control of the Druck pressure controller using the load cell as feedback. 


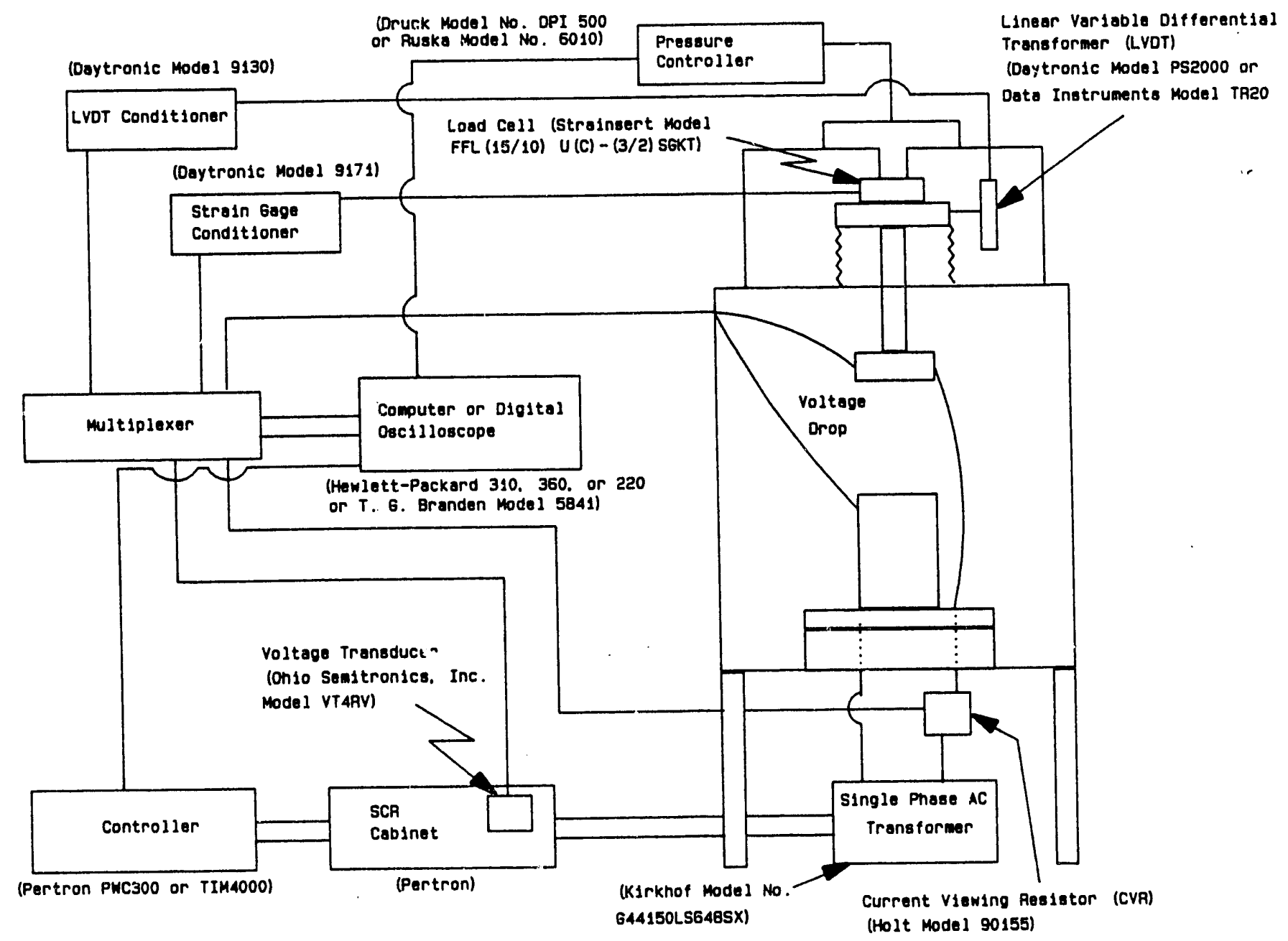

Figure I - Schematic of Mound upset welder and data acquisition systems. 
Calibration of the Data Acquisition Systems has resulted in the assignment of the following uncertainties:

$\begin{array}{ll}\text { Voltage } & \pm 2.5 \% \text { of reading } \\ \text { Current } & \pm 2.5 \% \text { of reading } \\ \text { Force } & \pm 20 \mathrm{lb}+0.2 \% \text { of reading } \\ \text { Displacement } & \pm 0.002 \mathrm{in} . \\ \text { Primary Voltage } & \pm 2 \% \text { of reading }\end{array}$

It should be noted that the current viewing resistors (30,000 ampere shunts) are not included in this uncertainty; only the system that monitors the shunt output is included.

\section{The 0.298-in. Plug Upset Weld}

\section{Joint Design}

The 0.298-in. diameter side-bonding upset weld joint design is depicted in Figure 2 along with the applicable drawing numbers. As previously mentioned, this joint design incorporates a straight-sided flange welded into a $9^{\circ}$ tapered hole. As the dimensions indicate, the flange/body interference can vary from +0.009 in. to +0.012 in. at the body surface.

For this particular study, the plugs (SNLL Drawing No. AY451513) were machined from 304L stainless steel bar stock purchased to specification P12323 [3] and Nitradd cleaned per SS454811 [4]. While P12323 specifies a minimum yield strength of $25.0 \mathrm{ksi}$. (thousand pounds per square inch) a yield strength of $40 \mathrm{ksi}$ would be typical for the plugs. The bodies (SNLL Drawing No. AY454931) were machined

sect Dog. No. Arss1513
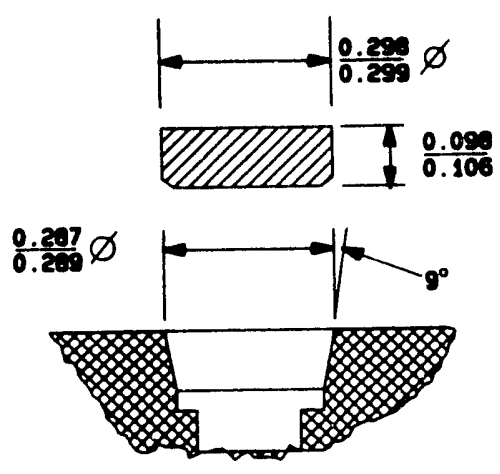

sincl om. No. AY45a931
Figure 2 - The 0.298-in. plug side-bonding upset weld joint design (dimensions in inches). from 304L stainless steel of varying yield strengths as summarized in Table 1.

After they are received at Mound and before they are welded, all parts are cleaned according to the procedures outlined in Tables 2 and 3. This cleaning is done to exercise as much control over cleanliness, and consequently the coefficient of friction, as reasonably possible. 


\section{Table 1 - SUMMARY CF 304L STAINLESS STEEL BODY MATERIALS}

\begin{tabular}{ccc} 
Material & $\begin{array}{c}\text { Yield Streingth } \\
\text { Specification } \\
\text { (ksi) }\end{array}$ & $\begin{array}{c}\text { Typical } \\
\text { Yield Strength } \\
\text { (ksi) }\end{array}$ \\
$\begin{array}{c}\text { Bar Stock } \\
\text { P12323 }\end{array}$ & $25.0 \mathrm{~min}$. & 40 \\
$\begin{array}{c}\text { Push Forging } \\
\text { P32162 }\end{array}$ & $65.0-80.0$ & 70 \\
$\begin{array}{c}\text { Coined Forging } \\
\text { AY454858 }\end{array}$ & $60.0-75.0$ & 61 \\
Die 1178 Forging & $60.0-75.0$ & 62 \\
\hline
\end{tabular}

\section{Table 2 - SUMMARY OF THE BODY CLEANING PROCEDURE}

Step 1. Wipe weld joint surface with cotton swab soaked in 1-1-1 trichloroethane.

Step 2. Wipe weld joint surface with a cotton swab and 50-50 ethanol/water mixture.

Step 3. Polish weld joint surface with 400 grit $\mathrm{Al}_{2} \mathrm{O}_{3}$ paper.

Step 4. Wipe weld joint surface with a cotton swab and 50-50 ethanol/water mixture until clean.

Step 5. Wipe weld joint surface with ethanol-soaked swab. 


\section{Table 3 - SUMMARY OF THE PLUG CLEANING PROCEDURE}

Step 1. Ultrasonically clean plugs in 1-1-1 trichloroethane.

Step 2. Ultrasonically clean plugs in a 50-50 ethanol/water mixture.

Step 3. Ultrasonically clean plugs in ethanol.

\section{Welding Procedure}

The requirements for the 0.298-in. plug upset weld are stated in SNLL Drawing No. AY451511 and specifications SS452908 [5] and SB452908 [6]. The principal requirements are that the weld withstand a 40,000-psi hydrostatic proof test and exhibit a bond quality of Class II or better for 0.055 in. in length as judged by SB452908. The welding procedure in Table 4 was demonstrated to meet these requirements. ${ }^{*}$

Table 4 - UPSET WELDING PROCEDURE FOR 0.298-IN. PLUG

Welding Force 1600-1800\#

Welding Heat $35-39 \%(10.75 / 13.00 \mathrm{kA})$

Welding Cycles 22-24

\section{Experimental Work}

During the course of developing the welding procedure for the 0.298 -in. plug, welds were made on bodies of four different conditions of 304L stainless steel. The materials and their yield strengths were summarized in Table 1. Besides bar stock [3], welds were also made on

"From a memo dated March 20, 1989, "Qualification of Upset Welder \#2 for Kyle B." from H. L. Cline to Component Records. EG\&G Mound Applied Technologies, Miamisburg, Ohio. 
Die 1178 forgings (SNLL Drawing No. AY454858) of material meeting the requirernents of SS454474 [7], push forgings (Rocky Flais Drawing No. P32162) of material meeting the requirements of P32813 Type $A$ [8], and coined forgings. When a run of Die 1178 forgings were produced which did not demonstrate sufficient yield strength, they were subjected to an additional hot coining operation and thereby became the coined forging. All welding data for plug welds made with the welding procedure in Table 4 have been summarized in Appendix $A$ for ease of comparison. Figure 3 is a photograph of a plug and body before welding. After welding, the samples were subjected to a 40,000-psi hydrostatic proof test prior to submission for metallographic analysis.

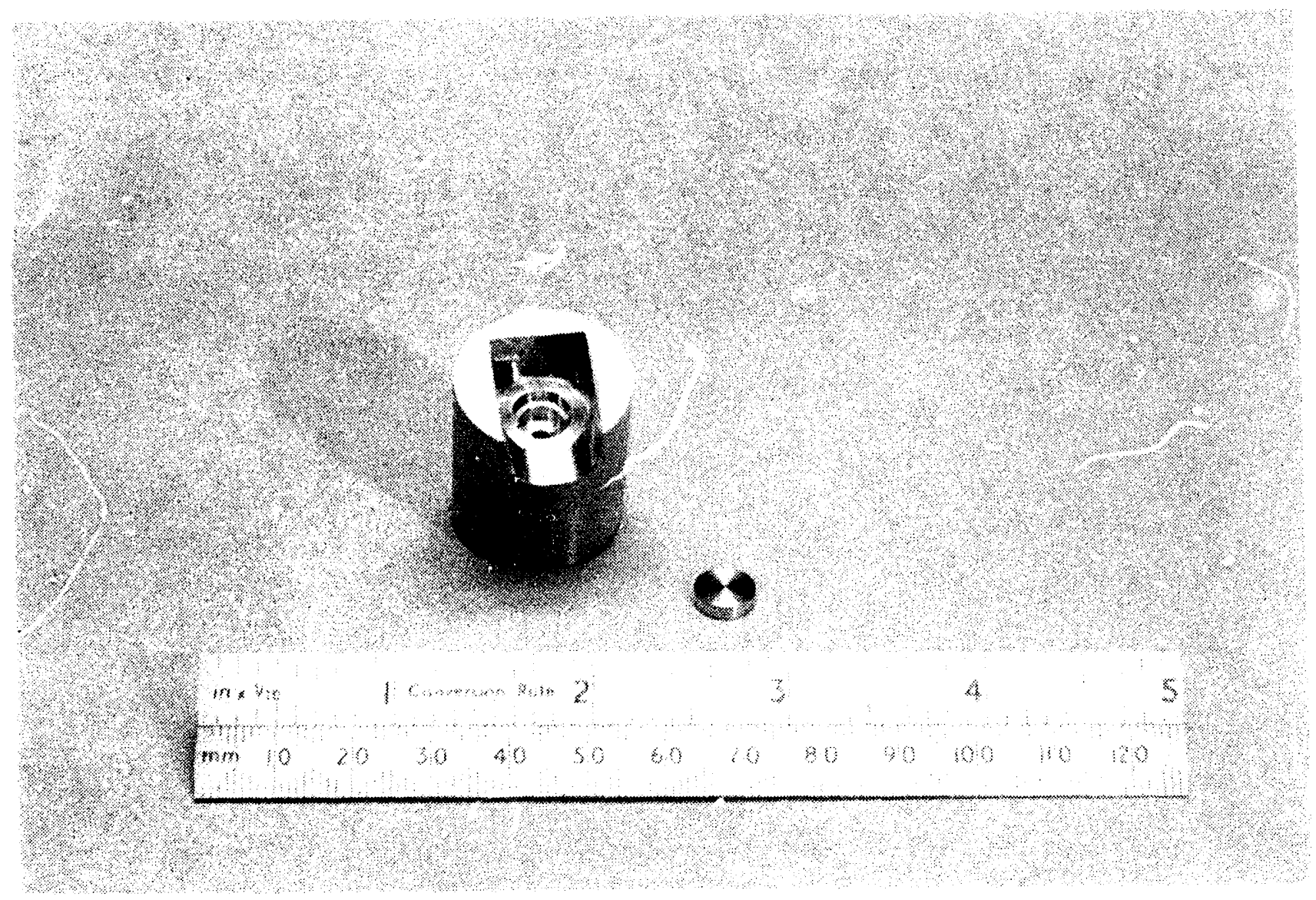

Figure 3 - Photograph of 0.298-in. plug and corresponding body.

It should be noted at this point that if the welding data are closely examined, two distinct populations appear to be among the cold displacem?nt data. This is indeed the case. During the course of this welding development effort, a modifisation in the measurement of the cold displacement was instituted. Experience with the measurement of cold displacement had revealed that the measurement was made up of at least three components. One component 
was that of the seating of the part in the welding fixture, which could amount to 0.001 to 0.003 in. A second component was the compliance of the part and fixture along with the weider itself under the welding load, which was shown to range from approximately 0.006 to 0.009 inches. And finally there was the component of interest, the displacement of the flange into the body (or weld joint) during the application of the welding force and prior to the application of the welding current. To measure true cold displacement, the welding procedure was changed so that a system compression measurement could be made. This is then subtracted from the displacement measured with the plug in position to arrive at the true cold displacement. Hence, the 0.006 or 0.007 in. difference between the two populations.

The table of coined forging welds also includes welds that exceed the force limits of the welding procedure previously mentioned. These were welds from the qualification of the welding procedure for production and as such were made so as to incorporate the uncertainties in the force measurement, $\pm 25 \mathrm{lb}$.

\section{Analysis of Data}

Figure 4 is a stacked bar graph showing the distribution of all Class II or better bond lengths. This is a fairly uniform distribution since the mean bond length for all welds is 0.085 in. (see Table 5), virtually the center of the distribution.

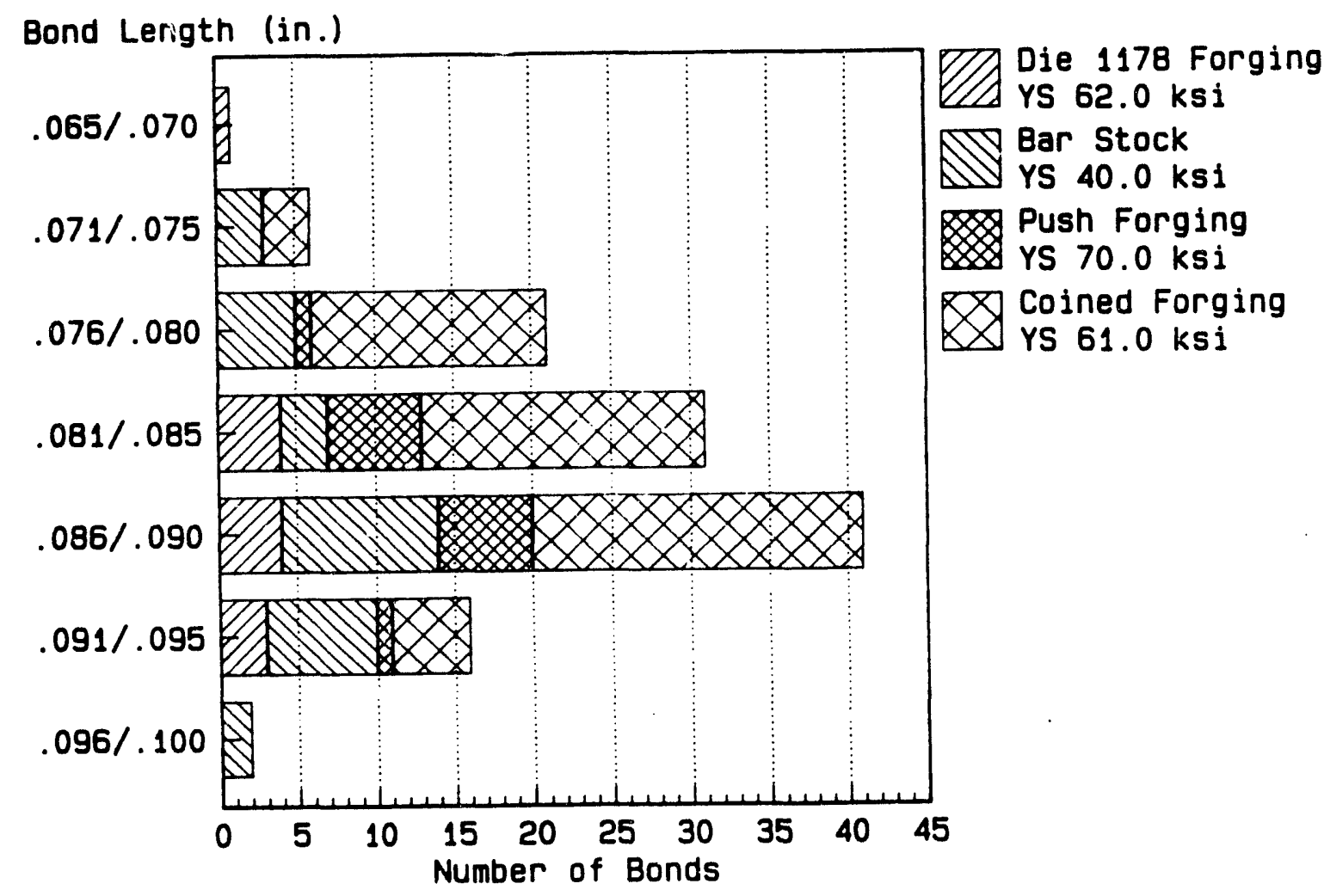

Figure 4 - Stacked bar graph of the distribution of Class II or better bond lengthr: as a function of the body material. 
To check for bond length differences between materials, a one-way analysis of variance was used to test whether observed differences in mean bond lengths (Table 5) could be attributed to chance or whether they are indicative of ac'dal differences among the corresponding population means. Mean bond lengths were checked for all plug welds made with the welding procedure in Table 4. This included welds on the aforementioned materials: bar stock, production forgings, push forgings, and coined forgings. The results of this analysis (Table 6) indicate that there was no significant difference in bond lengths between welds made on the different maierials. An F-ratio of 1.37 is not significant even at a $90 \%$ confidence interval $[(F 3,117) .90 \simeq 2.13]$. Thus with a constant $40 \mathrm{ksi}$ plug yield strength, body yield strength variations $o^{\text {f }} 40$ to $70 \mathrm{ksi}$ had no effect on bond quality as measured by Class $\|$ or better bond length for the 0.298 -in. upset weld.

\begin{tabular}{|c|c|c|c|c|c|c|}
\hline \multirow{2}{*}{ Level } & \multirow{2}{*}{$\begin{array}{l}\text { Count } \\
30\end{array}$} & \multirow{2}{*}{$\begin{array}{l}\text { Mear. } \\
0.08610\end{array}$} & \multirow{2}{*}{$\begin{array}{l}\text { Standard } \\
\text { Deviation } \\
0.007327\end{array}$} & \multirow{2}{*}{$\begin{array}{l}\text { Sten. Error } \\
\text { (Mean) } \\
0.001338\end{array}$} & \multicolumn{2}{|c|}{$\begin{array}{l}99 \% \text { Confidence } \\
\text { Intervals for Mear }\end{array}$} \\
\hline & & & & & 0.08241 & .08979 \\
\hline Coined Forging & g 62 & 0.08394 & 0.004848 & 0.000616 & 0.08230 & .08557 \\
\hline Die 1178 & 12 & 0.08633 & 0.006228 & 0.001798 & 0.08075 & .09192 \\
\hline Push Forging & 14 & 0.08529 & 0.003148 & 0.000841 & 0.08275 & .08782 \\
\hline Total & 118 & 0.08489 & & & & \\
\hline
\end{tabular}

\begin{tabular}{|lcccc|}
\hline \multicolumn{5}{|c|}{ Table 6 - ONE-WAY ANALYSIS OF VARIANCE } \\
Source of variation & d. f. & Sum of Squares & Mean Square & F-ratio \\
Between Groups & 3 & 0.000128 & $4.253 \mathrm{E}-005$ & 1.37 \\
Within Groups & 114 & 0.003546 & $3.110 \mathrm{E}-005$ & \\
Total (corrected) & 117 & 0.003674 & & \\
\hline
\end{tabular}




\section{The 0.440-in. Stem Upset Weld}

\section{Joint Design}

As with the 0.298-in. diameter plug weld. the 0.440-in. diameter stem side-bonding upset weld incorporates a straight-sided sece ong. Mo. Arass254 flange welded into a $9^{\circ}$ tapered hole. As the dimensions indicate, the flange/body interference can vary from -0.001 in. to +0.008 in. at the body surface.

The stem (SNLL Drawing No. AY451254) is machined from $304 \mathrm{~L}$ stainless steel bar stock purchased to specification P12323 [3] and Nitradd cleaned per SS454811 [4]. The body (SNLL Drawing No. AY452949) is machined from 304L stainless steel purchased to specification P12323 (see Figure 5). For this particular study, the stem and body were machined from bar stock that had been extruded to various levels of yield strength (Figure 6). Before welding, the bodies were cleaned according to the procedure outlined in Table 7 while the stems were used as Nitradd cleaned.

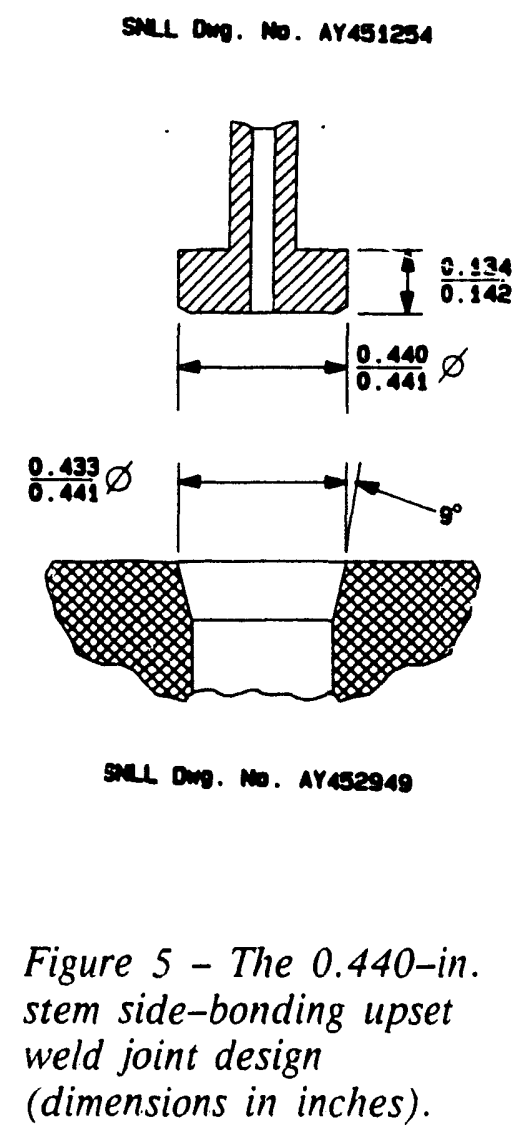

Table 7 - SUMMARY OF THE 0.440-IN. BODY CLEANING PROCEDURE

Step 1. Wipe weld joint surface with cotton swab soaked in ethanol.

Step 2. Polisin weld joint surface with 600 grit SiC paper.

Step 3. Wipe weld joint surface with cotton swab soaked in ethanol until clean. 


\section{Welding Procedure}

The requirements for the 0.440 -in. diameter stem upset weld are set forth in SNLL Drawing No. AY451694 and specifications SS452908 [5] and SB452908 [6]. The principal requirements are that the weld withstand a 40,000-psi hydrostatic proof test and exhibit a bond quality of Class II or better for 0.065 in. in length, as judged by SB452908.

As the data in Appendix $B$ indicate, these requirements were met by using welding parameters consisting of $5000 \mathrm{lb}$ of force, 30 cycles, and $20.9 \pm 0.1 \mathrm{kA}$ ( $63 \%$ heat).

\section{Experimental Work}

To evaluate the potential effect of yield strength on the 0.440 -in. stem weld, 304L stainless steel bar stock was extruded to four different yield strength conditions for the stem (36.0. 74.0, 112.0, and $141.0 \mathrm{ksi}$ ) and for the body (44.0,57.0,80.0, and $100.0 \mathrm{ksi})$. (Ipset welds were then made with the welding parameters previously mentioned. Figure 6 shows the combination of materials in which welds were produced for this study. Tiis figure is cross-referenced by weld number with the welding data summarized in Appendix $B$.

Figure 7 is a photograph of a 0.440 -in. body and stem before welding. After hydrostatic proof testing at $40,000 \mathrm{psi}$, the welds were submitted for metallographic evaluation.

\section{Stem Yield Strength (ksi)}

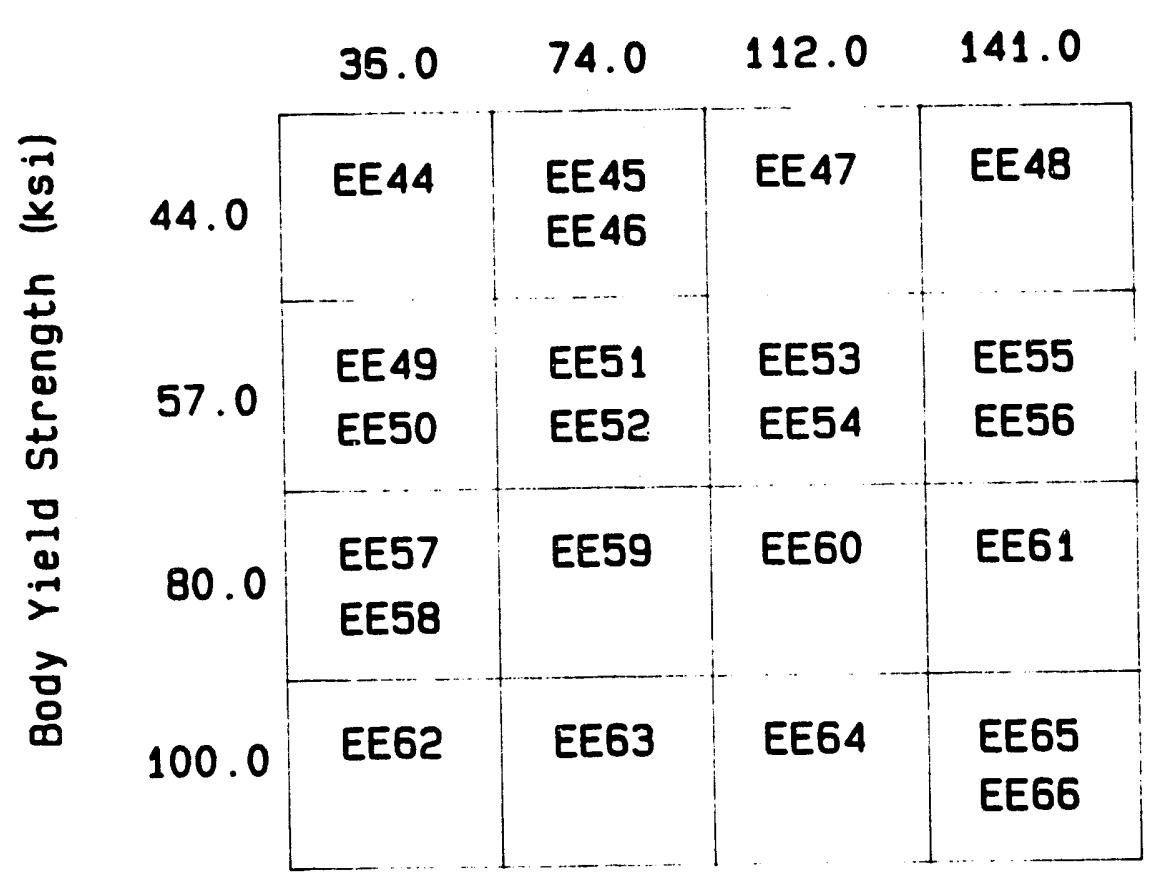

Figure 6 - The 0.440-in. stem upset weld material matrix. 


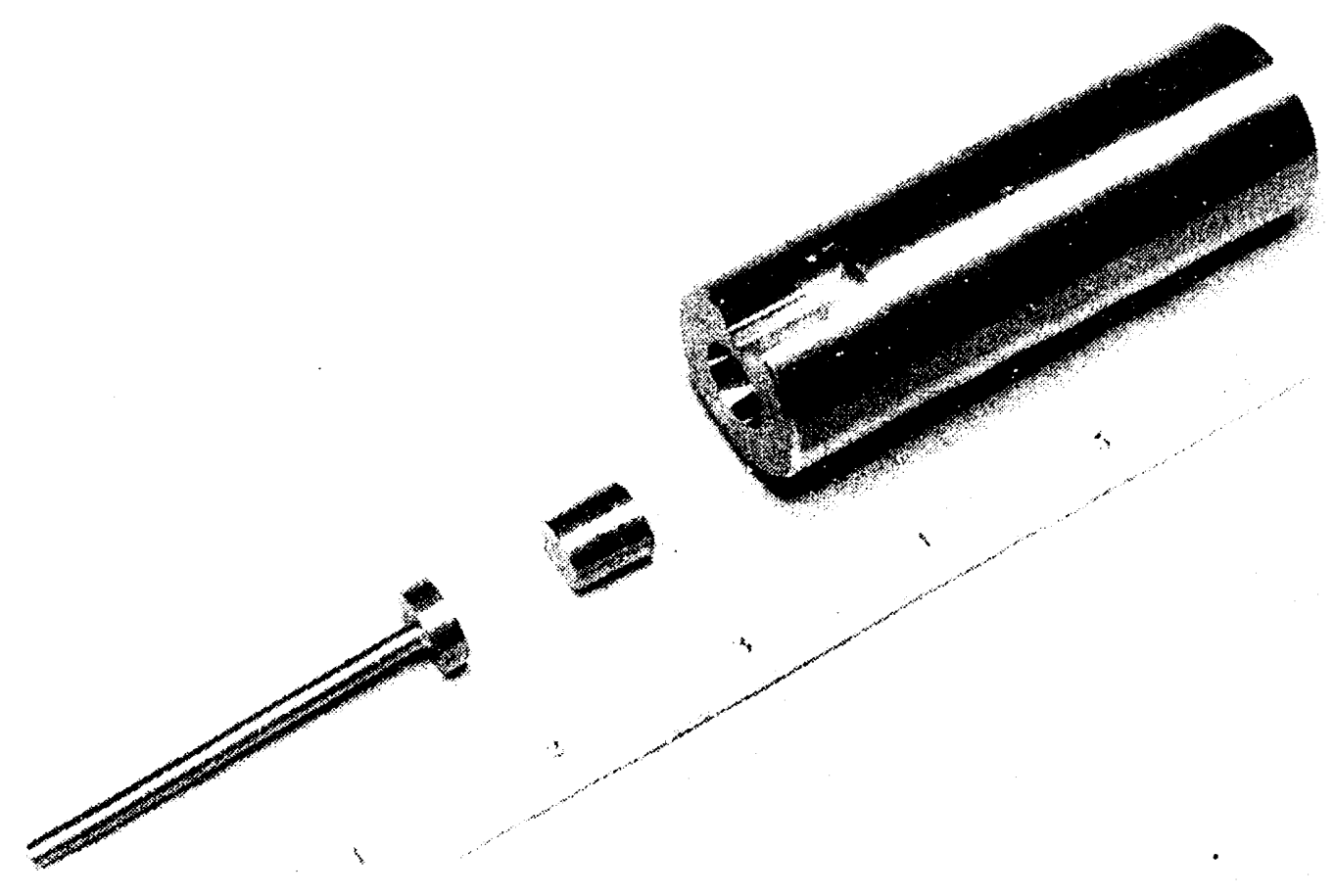

Figure 7 - Photograph of a 0.440-in. stem and corresponding body.

\section{Analysis of Data}

The graph in Figure 8 shows the mean bond length for the various strength combinations as a function of the stem yield strengths. With the exception of the $80.0 \mathrm{ksi}$ bodies, the yield strength appears to have little or no effect on the mean bond length. An examination of the data shows that welds EE60 and EE61 produced unusually low bond lengths for $80.0 \mathrm{ksi}$. Witti the $100.0 \mathrm{ksi}$ data returning to normal and the lack of replicates for the EE60 and EE61 material combinations, it is unclear whether this is an effect or an artifact of the data. Many conditions other than material yield strength (for example, part cleanliness and part alignment) could contribute to decreased bond length.

The mean bond lengths for the various strength combinations were then graphed as a function of the body yield strengths (Figure 9). This graph indicates a loss of bond length with increasing stem yield strength for both 112.0 and $141.0 \mathrm{ksi}$ stems.

To get a quantitative handle on what appeared to be a potential yield strength effect, an analysis of variance was conducted. The results of this analysis are presented in Table 8. As the data indicate. both the body and stem yield strengths are significant factors, as is their interaction. Only the replication of the welds within a cell is not significant. 


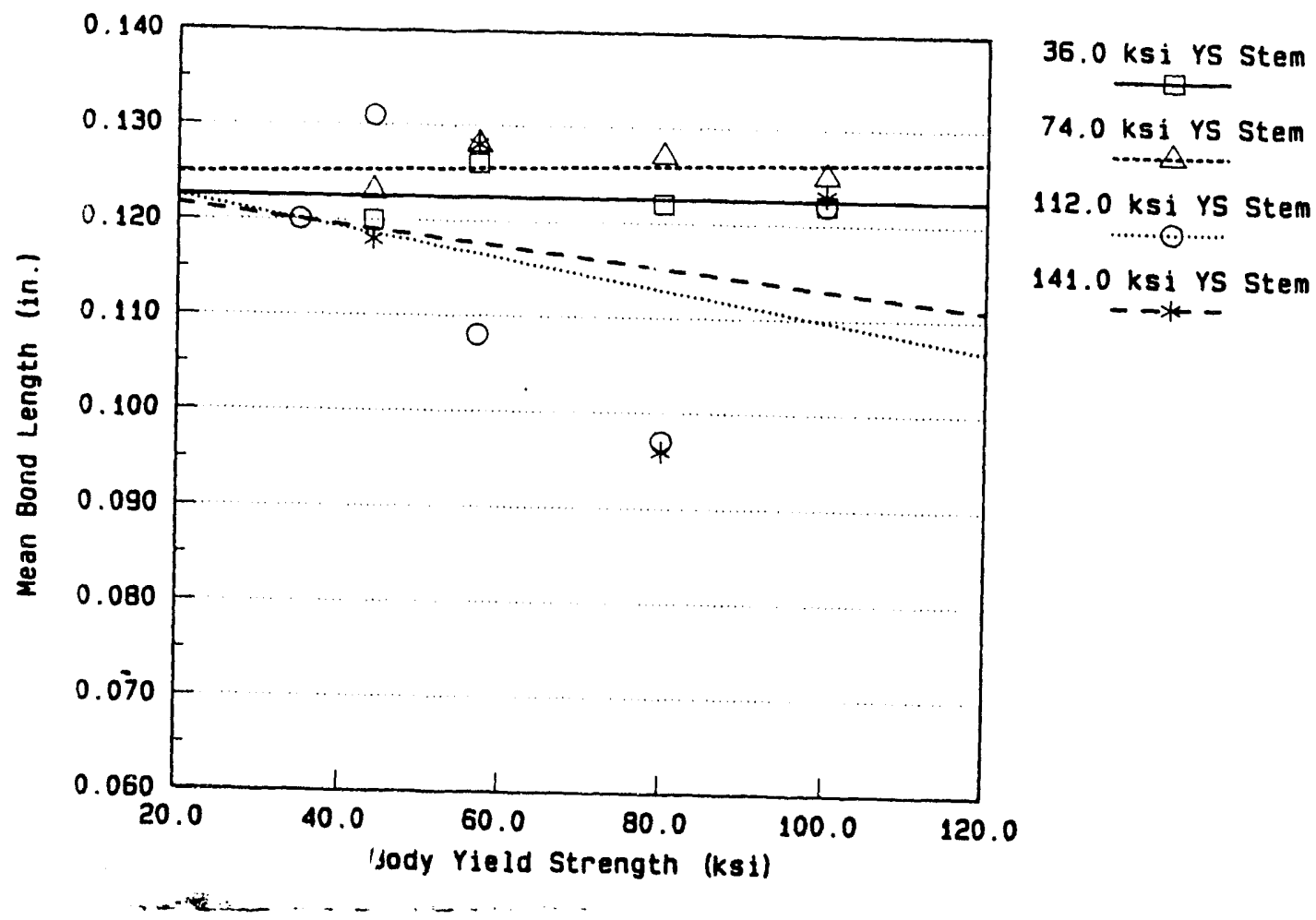

Figure 8 - The mean bond length as a function of the stem yield strength for the different body yield strengths.

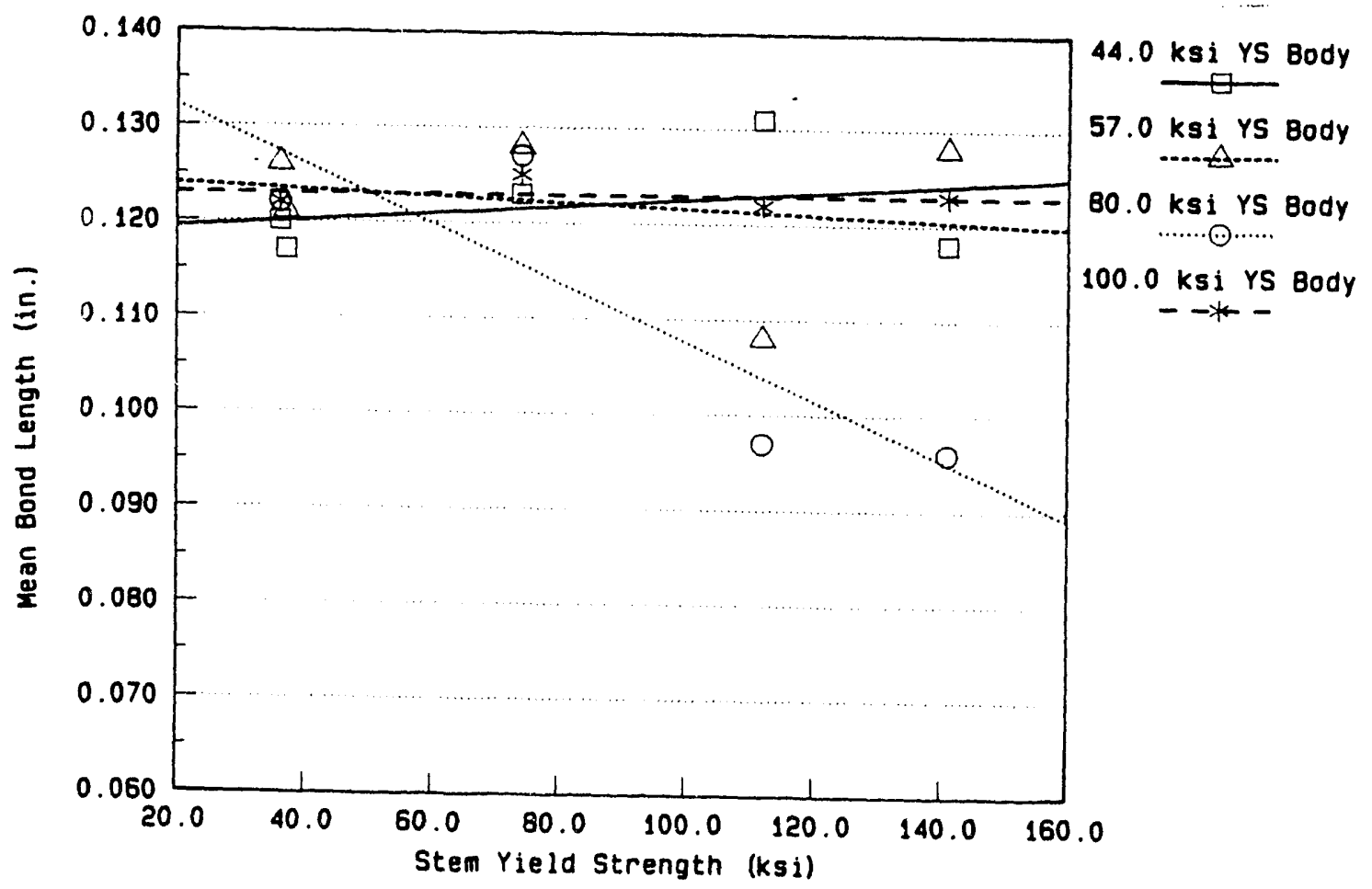

Figure 9 - The mean bond length as a function of the body yield strength for the different stem yield strengths. 
Table 8 - GENERAL ANALYSIS OF VARIANCE FOR BOND LENGTH

\begin{tabular}{|c|c|c|c|c|}
\hline Source of Variation & d.f. & Sum of Squares & Mean Square & F-Ratio \\
\hline Body Yield Strength(A) & 3 & $1.8628 \mathrm{E}-03$ & $6.2094 E-04$ & 12.74 \\
\hline Stem Yield Strength $(B)$ & 3 & $1.3913 \mathrm{E}-03$ & 4.6377E-04 & 9.51 \\
\hline Replicates $(C)$ & 3 & $1.1768 \mathrm{E}-04$ & 3.9226E-05 & 0.80 \\
\hline$A * B$ & 9 & $3.4138 \mathrm{E}-03$ & 3.7931E-04 & 7.78 \\
\hline$A^{*} B^{*} C$ & 27 & $1.3161 \mathrm{E}-03$ & 4.8744E-05 & \\
\hline Total & 45 & 8.1017E-03 & & \\
\hline Grand Average & 1 & $9.0869 E-01$ & $\begin{array}{l}F(3, \\
F(9 .\end{array}$ & $\begin{array}{l}99=5.13 \\
99=2.85\end{array}$ \\
\hline
\end{tabular}

While the analysis of variance indicates that both the body and stem yield strengths are significant, it is still possible that welds EE60 and EE61 are having a disproportionate influence on the significance of the body yield strength and the interaction of the yield strengths. This would not be the case for the significance of the stem yield strength.

To isolate those material conditions that were leading to the significance of the factors, a Tukey pairwise comparison of the bond length was performed for both the body yield strength and the stem yield strength. These tests were conducted at a confidence level of $99 \%$. The results are presented in Tables 9 and 10. As expected, the mean bond length for a body yield strength of $80.0 \mathrm{ksi}$ was in a group all its own, indicating that it was the cause of the significance for body yield strength on bond length. Again, this may be an artifact of the data and not an actual effect.

In the case of the Tukey comparison of bond length by stem yield strength, the data broke out into two overlapping homogeneous groups, indicating the more widespread contribution to the stem yield strength's significance.

Table 9 - TUKEY (HSD) PAIRWISE COMPARISON OF MEANS. BOND LENGTH BY BODY YIELD STRENGTH (99\% CONFIDENCE).

Body Yield Strength

Mean

Homogeneous Groups

$\begin{array}{rl}44.0 \mathrm{ksi} & 1.224 \mathrm{E}-01 \\ 57.0 \mathrm{ksi} & 1.222 \mathrm{E}-01 \\ 100.0 \mathrm{ksi} & 1.222 \mathrm{E}-01 \\ 80.0 \mathrm{ksi} & 1.098 \mathrm{E}-01\end{array}$

I

I

I 
Table 10 - TUKEY (HSD) PAIRWISE COMPARISON OF MEANS. BOND LENGTH BY STEM YIELD STRENGTH ( $99 \%$ CONFIDENCE).

Stem Yield Strength

$74.0 \mathrm{ksi}$

$36.0 \mathrm{ksi}$

$141.0 \mathrm{ksi}$

$112.0 \mathrm{ksi}$
Mean

1.251E-01

1.222E-01

1.156E-01

1.138E-01
Homogeneous Groups

I

I I

. 1

. 1

\section{Conclusions}

The development efforts for the 0.298-in. and 0.440-in. diameter side-bonding upset weld have led to the following conclusions about the effect of yield strength:

Body yield strengths of up to $70.0 \mathrm{ksi}$ do not effect bond quality as measured by bond length. The effect of body yield strengths beyond $70.0 \mathrm{ksi}$ is unclear. The most encouraging aspect of this result is that production does not usually involve parts whose yield strength exceeds $70.0 \mathrm{ksi}$ to $75.0 \mathrm{ksi}$.

- Stem yield strength does have a statistically significant inverse relationship with bond quality as measured by bond length. While significant, the magnitude of the bond length reduction is small and, in the case of the 0.440 -in. stem weld, was certainly acceptable. Therefore, any other side-bonding development effort will require an independent analysis as to whether particular attention is to be paid to the stem material. In many cases, this decision will be dictated by other considerations such as the need for pinch welding.

Because of the different stress distributions in a plug as opposed to a stem (due to the hole) during the application of the welding force, this conclusion cannot be directly extrapolated to plug welds. The feeling is that the difference would be minimal; however, caution should be shown, particularly since the body-stem yield strength interaction is significant.

- While both the body and stem yield strengths are significant factors, as is their interaction, the magnitude of the loss of bond length is small. A well-developed upset 
welding procedure with a sufficient margin of safety could easily accommodate the effect of yield strength experienced in this work.

Although the stem yield strength was found to be significant, it is unlikely that stem strengths of greater than $112 \mathrm{ksi}$ are usable because of the difficulty of producing satisfactory pinch welds at these levels.

\section{Acknowledgments}

The authors would like to thank D. M. Kasberg and J. W. O'Connor for providing not only information but the majority of the parts welded in these studies. Special acknowledgment goes to J. R. Spingarn, who was the technical consultant for the work performed in this report.

\section{References}

1. M. A. Perkins, Upset Weld Development for the W87 Vineyard (U), MLM-MC-86-25-0001, Monsanto Research Corporation (May 1986), 41 pp. (C-RD)

2. R. G. Miller and M. A. Perkins, Kyle B Welding Development (U), MLM-MC-90-25-0001. EG\&G Mound Applied Teshnologies (May 1990). 51pp. (C-RD).

3. P12323, "Material Specification for 304L VAR Machining Stock," Rockwell International, Rocky Flats Plant, Golden, Colorado.

4. SS454811, "Cleaning of Parts, Sub-Assemblies and Asseinblies," Sandia National Laboratories, Livermore, California.

5. SS452908, "Upset Welds, Side Bonding, 304L-to--304L Stainless Steel," Sandia National Laboratories, Livermore, California.

6. SB452908, "Upset Welds, Side Bonding, 304L-to-304L Stainless Steel, Microstructure Standard," Sandia National Laboratories, Livermore, California.

7. SS454474, "304L VAR Bar (Weld Critical Applications)," Sandia National Laboratories, Livermore, California.

8. P32813, "304L VAR Corrosion Resistant Steel for Special Applications," Rockwell International, Rocky Flats Plant, Golden, Colorado. 
Appendix A: 0.298-in. Plug Welding Data 
Table A-1 - SUMMARY OF ALL 0.298 IN. PLUG WELDS ON PUSH FORGINGS.

\begin{tabular}{|c|c|c|c|c|c|c|c|c|c|}
\hline $\begin{array}{c}\text { Weld } \\
\text { \# }\end{array}$ & $\begin{array}{c}\text { Cycles } \\
\underline{H}\end{array}$ & $\begin{array}{c}\text { RMS } \\
\text { Current } \\
\text { (kA) }\end{array}$ & $\begin{array}{c}\text { RMS } \\
\text { Voltage } \\
\text { (volts) }\end{array}$ & $\begin{array}{l}\text { Force } \\
\text { (lbs) }\end{array}$ & $\begin{array}{l}\text { Heat } \\
\text { Input } \\
\text { (kJ) }\end{array}$ & $\begin{array}{c}\text { Cold } \\
\text { Displacement } \\
\text { (in.) }\end{array}$ & $\begin{array}{c}\text { Hot } \\
\text { Displacement } \\
\text { (in.) }\end{array}$ & $\begin{array}{c}\text { Total } \\
\text { Displacement } \\
\text { (in.) }\end{array}$ & $\begin{array}{l}\text { Bond } \\
\text { Length } \\
\text { (in.) }\end{array}$ \\
\hline $\begin{array}{l}\text { 5PF } \\
\text { 6PF } \\
7 P F \\
8 P F \\
1 X P F\end{array}$ & $\begin{array}{l}22 \\
22 \\
23 \\
23 \\
23\end{array}$ & $\begin{array}{l}11.60 \\
11.50 \\
12.11 \\
11.96 \\
12.08\end{array}$ & $\begin{array}{l}1.98 \\
2.00 \\
2.00 \\
1.91 \\
1.83\end{array}$ & $\begin{array}{l}1800 \\
1800 \\
1700 \\
1700 \\
1700\end{array}$ & $\begin{array}{l}7.73 \\
7.98 \\
8.72 \\
8.05 \\
8.16\end{array}$ & $\begin{array}{l}0.013 \\
0.013 \\
0.013 \\
0.013 \\
0.013\end{array}$ & $\begin{array}{l}0.061 \\
0.061 \\
0.061 \\
0.060 \\
0.065\end{array}$ & $\begin{array}{l}0.074 \\
0.074 \\
0.074 \\
0.073 \\
0.078\end{array}$ & $\begin{array}{l}0.086 / 0.087 \\
0.085 / 0 / 086 \\
0.082 / 0.088 \\
0.084 / 0.084 \\
0.080 / 0.086\end{array}$ \\
\hline $\begin{array}{l}2 X P F \\
1 P F\end{array}$ & $\begin{array}{l}23 \\
24\end{array}$ & $\begin{array}{l}12.28 \\
12.37\end{array}$ & $\begin{array}{l}1.76 \\
2.19\end{array}$ & $\begin{array}{l}1700 \\
1600\end{array}$ & $\begin{array}{c}7.93 \\
10.30\end{array}$ & $\begin{array}{l}0.011 \\
0.013\end{array}$ & $\begin{array}{l}0.066 \\
0.065\end{array}$ & $\begin{array}{l}0.077 \\
0.078\end{array}$ & $\begin{array}{l}0.082 / 0.083 \\
0.089 / 0.092\end{array}$ \\
\hline
\end{tabular}

Table A-2 - SUMMARY OF ALL 0.298 IN. PLUG WELDS ON DIE 1178 FORGINGS.

\begin{tabular}{|ccccccccccc|}
\hline $\begin{array}{c}\text { Weld } \\
\#\end{array}$ & $\begin{array}{c}\text { Cycles } \\
\#\end{array}$ & $\begin{array}{c}\text { RMS } \\
\text { Current } \\
\text { (KA) }\end{array}$ & $\begin{array}{c}\text { RMS } \\
\text { Voltage } \\
\text { (volts) }\end{array}$ & $\begin{array}{c}\text { Force } \\
\text { (lbs) }\end{array}$ & $\begin{array}{c}\text { Heat } \\
\text { Input } \\
\text { (kJ) }\end{array}$ & $\begin{array}{c}\text { Cold } \\
\text { Displacement } \\
\text { (in.) }\end{array}$ & $\begin{array}{c}\text { Hot } \\
\text { Displacement } \\
\text { (in.) }\end{array}$ & $\begin{array}{c}\text { Total } \\
\text { Displacement } \\
\text { (in.) }\end{array}$ & $\begin{array}{c}\text { Bond } \\
\text { Length } \\
\text { (in.) }\end{array}$ \\
$8 \mathrm{~F}$ & 22 & 11.55 & 1.91 & 1800 & 7.84 & 0.014 & 0.065 & 0.079 & $0.085 / 0.085$ \\
$12 \mathrm{~F}$ & 22 & 11.59 & 1.85 & 1800 & 7.60 & 0.011 & 0.064 & 0.075 & $0.084 / 0.087$ \\
$1 \mathrm{~F}$ & 23 & 11.98 & 1.98 & 1700 & 8.67 & 0.014 & 0.065 & 0.079 & $0.091 / 0.091$ \\
$9 \mathrm{~F}$ & 24 & 12.56 & 2.07 & 1600 & 9.74 & 0.014 & 0.067 & 0.081 & $0.089 / 0.096$ \\
$3 \mathrm{~F}$ & 24 & 12.60 & 2.12 & 1600 & 10.32 & 0.013 & 0.067 & 0.080 & $0.084 / 0.087$ \\
$10 \mathrm{~F}$ & 24 & 12.64 & 1.98 & 1600 & 9.71 & 0.013 & 0.062 & 0.075 & $0.070 / 0.087$ \\
\hline
\end{tabular}


Table A-3 - SUMMARY OF ALL 0.298 IN. WELDS ON COINED FORGINGS.

\begin{tabular}{|c|c|c|c|c|c|c|c|c|c|}
\hline $\begin{array}{c}\text { Weld } \\
\text { 茾 }\end{array}$ & $\begin{array}{c}\text { Cycles } \\
\#\end{array}$ & $\begin{array}{c}\text { RMS } \\
\text { Current } \\
\text { (kA) }\end{array}$ & $\begin{array}{c}\text { RMS } \\
\text { Voltage } \\
\text { (volts) } \\
\end{array}$ & $\begin{array}{l}\text { Force } \\
\text { (lbs) }\end{array}$ & $\begin{array}{l}\text { Heat } \\
\text { Input } \\
\text { (kJ) }\end{array}$ & $\begin{array}{l}\text { Cold } \\
\text { Displacement } \\
\text { (in.) }\end{array}$ & $\begin{array}{c}\text { Hot } \\
\text { Displacement } \\
\text { (in.) }\end{array}$ & $\begin{array}{c}\text { Total } \\
\text { Displacement } \\
\text { (in.) }\end{array}$ & $\begin{array}{l}\text { Bond } \\
\text { Length } \\
\text { (in.) }\end{array}$ \\
\hline $\begin{array}{l}7274 \\
7032 \\
7075 \\
7050 \\
7266\end{array}$ & $\begin{array}{l}22 \\
22 \\
22 \\
22 \\
22\end{array}$ & $\begin{array}{l}10.96 \\
11.24 \\
11.31 \\
11.23 \\
10.76\end{array}$ & $\begin{array}{l}1.70 \\
1.76 \\
1.76 \\
1.75 \\
1.71\end{array}$ & $\begin{array}{l}1843 \\
1840 \\
1839 \\
1841 \\
1830\end{array}$ & $\begin{array}{l}6.74 \\
7.08 \\
6.98 \\
7.03 \\
6.74\end{array}$ & $\begin{array}{l}0.006 \\
0.007 \\
0.005 \\
0.007 \\
0.007\end{array}$ & $\begin{array}{l}0.064 \\
0.063 \\
0.063 \\
0.064 \\
0.064\end{array}$ & $\begin{array}{l}0.070 \\
0.070 \\
0.068 \\
0.071 \\
0.071\end{array}$ & $\begin{array}{l}0.080 / 0.083 \\
0.077 / 0.088 \\
0.089 / 0.075 \\
0.088 / 0.077 \\
0.085 / 0.084\end{array}$ \\
\hline $\begin{array}{l}27 C F \\
31 C F \\
42 C F \\
2 C F \\
16 C F\end{array}$ & $\begin{array}{l}23 \\
23 \\
23 \\
23 \\
23\end{array}$ & $\begin{array}{l}12.20 \\
12.17 \\
12.23 \\
12.17 \\
12.05\end{array}$ & $\begin{array}{l}1.81 \\
1.77 \\
1.79 \\
1.83 \\
1.84\end{array}$ & $\begin{array}{l}1700 \\
1700 \\
1700 \\
1700 \\
1700\end{array}$ & $\begin{array}{l}8.10 \\
7.92 \\
8.04 \\
7.97 \\
8.09\end{array}$ & $\begin{array}{l}0.011 \\
0.011 \\
0.011 \\
0.017\end{array}$ & $\begin{array}{l}0.065 \\
0.066 \\
0.065 \\
0.063 \\
0.061\end{array}$ & $\begin{array}{l}0.076 \\
0.077 \\
0.076 \\
0.080\end{array}$ & $\begin{array}{l}0.084 / 0.086 \\
0.086 / 0.084 \\
0.081 / 0.082 \\
0.089 / 0.092 \\
0.086 / 0.090\end{array}$ \\
\hline $\begin{array}{l}13 C F \\
8 C F \\
22 C F \\
7072 \\
7080\end{array}$ & $\begin{array}{l}23 \\
23 \\
23 \\
23 \\
23\end{array}$ & $\begin{array}{l}12.00 \\
12.02 \\
11.94 \\
11.58 \\
11.88\end{array}$ & $\begin{array}{l}1.84 \\
1.85 \\
1.8 \% \\
1.90 \\
1.82\end{array}$ & $\begin{array}{l}1700 \\
1700 \\
1700 \\
1718 \\
1717\end{array}$ & $\begin{array}{l}8.04 \\
8.11 \\
8.03 \\
8.04 \\
7.90\end{array}$ & $\begin{array}{l}0.012 \\
0.013 \\
0.012 \\
0.007 \\
0.004\end{array}$ & $\begin{array}{l}0.066 \\
0.069 \\
0.068 \\
0.065 \\
0.066\end{array}$ & $\begin{array}{l}0.078 \\
0.082 \\
0.080 \\
0.072 \\
0.070\end{array}$ & $\begin{array}{l}0.088 / 0.093 \\
0.089 / 0.090 \\
0.087 / 0.085 \\
0.086 / 0.078 \\
0.079 / 0.084\end{array}$ \\
\hline $\begin{array}{l}7063 \\
7042 \\
7078 \\
7066 \\
7077\end{array}$ & $\begin{array}{l}23 \\
23 \\
23 \\
23 \\
23\end{array}$ & $\begin{array}{l}11.87 \\
11.59 \\
11.68 \\
11.66 \\
11.54\end{array}$ & $\begin{array}{l}1.83 \\
1.87 \\
1.86 \\
1.88 \\
1.89\end{array}$ & $\begin{array}{l}1718 \\
1719 \\
1702 \\
1702 \\
1703\end{array}$ & $\begin{array}{l}7.99 \\
7.92 \\
7.91 \\
8.00 \\
7.91\end{array}$ & $\begin{array}{l}0.006 \\
0.006 \\
0.005 \\
0.006 \\
0.007\end{array}$ & $\begin{array}{l}0.065 \\
0.065 \\
0.065 \\
0.065 \\
0.066\end{array}$ & $\begin{array}{l}0.071 \\
0.071 \\
0.070 \\
0.071 \\
0.073\end{array}$ & $\begin{array}{l}0.074 / 0.093 \\
0.080 / 0.085 \\
0.086 / 0.074 \\
0.080 / 0.087 \\
0.087 / 0.081\end{array}$ \\
\hline $\begin{array}{l}7035 \\
7051 \\
7047 \\
7049 \\
7031\end{array}$ & $\begin{array}{l}23 \\
23 \\
23 \\
23 \\
23\end{array}$ & $\begin{array}{l}11.72 \\
11.83 \\
11.73 \\
11.92 \\
11.53\end{array}$ & $\begin{array}{l}1.87 \\
1.84 \\
1.87 \\
1.82 \\
1.85\end{array}$ & $\begin{array}{l}1718 \\
1717 \\
1720 \\
1718 \\
1717\end{array}$ & $\begin{array}{l}8.04 \\
7.96 \\
8.06 \\
7.96 \\
7.83\end{array}$ & $\begin{array}{l}0.005 \\
0.007 \\
0.006 \\
0.006 \\
0.005\end{array}$ & $\begin{array}{l}0.066 \\
0.065 \\
0.064 \\
0.065 \\
0.064\end{array}$ & $\begin{array}{l}0.071 \\
0.072 \\
0.070 \\
0.071 \\
0.069\end{array}$ & $\begin{array}{l}0.081 / 0.085 \\
0.083 / 0.092 \\
0.082 / 0.082 \\
0.086 / 0.076 \\
0.081 / 0.080\end{array}$ \\
\hline $\begin{array}{l}7264 \\
7070 \\
7060 \\
7270 \\
7052\end{array}$ & $\begin{array}{l}23 \\
24 \\
24 \\
24 \\
24\end{array}$ & $\begin{array}{l}11.72 \\
12.51 \\
12.85 \\
12.78 \\
12.72\end{array}$ & $\begin{array}{l}1.83 \\
1.99 \\
1.94 \\
1.90 \\
1.92\end{array}$ & $\begin{array}{l}1703 \\
1594 \\
1592 \\
1580 \\
1581\end{array}$ & $\begin{array}{l}7.84 \\
9.60 \\
9.39 \\
9.12 \\
9.38\end{array}$ & $\begin{array}{l}0.006 \\
0.005 \\
0.006 \\
0.006 \\
0.005\end{array}$ & $\begin{array}{l}0.066 \\
0.065 \\
0.067 \\
0.067 \\
0.068\end{array}$ & $\begin{array}{l}0.072 \\
0.070 \\
0.073 \\
0.073 \\
0.073\end{array}$ & $\begin{array}{l}0.081 / 0.086 \\
0.090 / 0.077 \\
0.091 / 0.080 \\
0.090 / 0.079 \\
0.080 / 0.088\end{array}$ \\
\hline 7275 & 24 & 12.50 & 1.92 & 1575 & 8.81 & 0.004 & 0.066 & 0.070 & $0.082 / 0.080$ \\
\hline
\end{tabular}


Table A-4 - SUMMARY OF ALL 0.298 IN. PLUG WELDS ON BAR STOCK.

\begin{tabular}{|c|c|c|c|c|c|c|c|c|c|}
\hline $\begin{array}{c}\text { Weld } \\
\text { \# }\end{array}$ & $\begin{array}{c}\text { Cycles } \\
\underline{\#}\end{array}$ & $\begin{array}{l}\text { RMS } \\
\text { Current } \\
\text { (KA) }\end{array}$ & $\begin{array}{c}\text { RMS } \\
\text { Voltage } \\
\text { (volts) } \\
\end{array}$ & $\begin{array}{l}\text { Force } \\
\text { (lbs) }\end{array}$ & $\begin{array}{l}\text { Heat } \\
\text { Input } \\
(k J)\end{array}$ & $\begin{array}{c}\text { Cold } \\
\text { Displacement } \\
\text { (in.) }\end{array}$ & $\begin{array}{c}\text { Hot } \\
\text { Displ acerrent } \\
\text { (in.) }\end{array}$ & $\begin{array}{c}\text { Total } \\
\text { Displacement } \\
\text { (in.) }\end{array}$ & $\begin{array}{l}\text { Bond } \\
\text { Length } \\
\text { sin.) }\end{array}$ \\
\hline $\begin{array}{l}T-9 \\
T-1 \\
T-2 \\
T-10 \\
A B 21\end{array}$ & $\begin{array}{l}22 \\
23 \\
23 \\
23 \\
23\end{array}$ & $\begin{array}{l}11.65 \\
12.04 \\
12.06 \\
12.05 \\
11.91\end{array}$ & $\begin{array}{l}1.95 \\
1.99 \\
2.01 \\
1.89 \\
1.95\end{array}$ & $\begin{array}{l}1800 \\
1700 \\
1700 \\
1700 \\
1700\end{array}$ & $\begin{array}{l}7.68 \\
8.65 \\
8.74 \\
8.15 \\
8.58\end{array}$ & $\begin{array}{l}0.014 \\
0.015 \\
0.017 \\
0.016 \\
0.012\end{array}$ & $\begin{array}{l}0.066 \\
0.063 \\
0.059 \\
0.067 \\
0.062\end{array}$ & $\begin{array}{l}0.080 \\
0.078 \\
0.076 \\
0.083 \\
0.074\end{array}$ & $\begin{array}{l}0.074 / 0.073 \\
0.077 / 0.078 \\
0.080 / 0.080 \\
0.071 / 0.076 \\
0.083 / 0.086\end{array}$ \\
\hline $\begin{array}{l}\text { AB23 } \\
A B 25 \\
\text { AB27 } \\
\text { MH37 } \\
\text { MH38 }\end{array}$ & $\begin{array}{l}23 \\
23 \\
23 \\
23 \\
23\end{array}$ & $\begin{array}{l}12.24 \\
12.51 \\
12.03 \\
11.75 \\
12.14\end{array}$ & $\begin{array}{l}1.83 \\
1.90 \\
1.88 \\
2.04 \\
2.06\end{array}$ & $\begin{array}{l}1700 \\
1700 \\
1700 \\
1700 \\
1700\end{array}$ & $\begin{array}{l}8.14 \\
8.42 \\
8.31 \\
8.94 \\
9.35\end{array}$ & $\begin{array}{l}0.011 \\
0.012 \\
0.011 \\
0.015 \\
0.015\end{array}$ & $\begin{array}{l}0.064 \\
0.062 \\
0.063 \\
0.067 \\
0.066\end{array}$ & $\begin{array}{l}0.075 \\
0.074 \\
0.074 \\
0.082 \\
0.081\end{array}$ & $\begin{array}{l}0.086 / 0.086 \\
0.087 / 0.087 \\
0.087 / 0.087 \\
0.089 / 0.092 \\
0.095 / 0.090\end{array}$ \\
\hline $\begin{array}{l}\text { MH39 } \\
\text { MH40 } \\
\text { MH41 } \\
\text { MH42 } \\
T-5\end{array}$ & $\begin{array}{l}23 \\
23 \\
23 \\
23 \\
24\end{array}$ & $\begin{array}{l}12.25 \\
12.19 \\
12.17 \\
12.20 \\
12.65\end{array}$ & $\begin{array}{l}2.00 \\
2.02 \\
2.05 \\
2.02 \\
2.05\end{array}$ & $\begin{array}{l}1700 \\
1700 \\
1700 \\
1700 \\
1600\end{array}$ & $\begin{array}{l}9.19 \\
9.23 \\
9.31 \\
9.20 \\
9.59\end{array}$ & $\begin{array}{l}0.017 \\
0.017 \\
0.014 \\
0.014 \\
0.013\end{array}$ & $\begin{array}{l}0.064 \\
0.064 \\
0.067 \\
0.068 \\
0.071\end{array}$ & $\begin{array}{l}0.081 \\
0.081 \\
0.081 \\
0.082 \\
0.084\end{array}$ & $\begin{array}{l}0.095 / 0.095 \\
0.092 / 0.090 \\
0.097 / 0.090 \\
0.099 / 0.091 \\
0.085 / 0.085\end{array}$ \\
\hline
\end{tabular}


Appendix B: 0.440-in. Stem Welding Data 


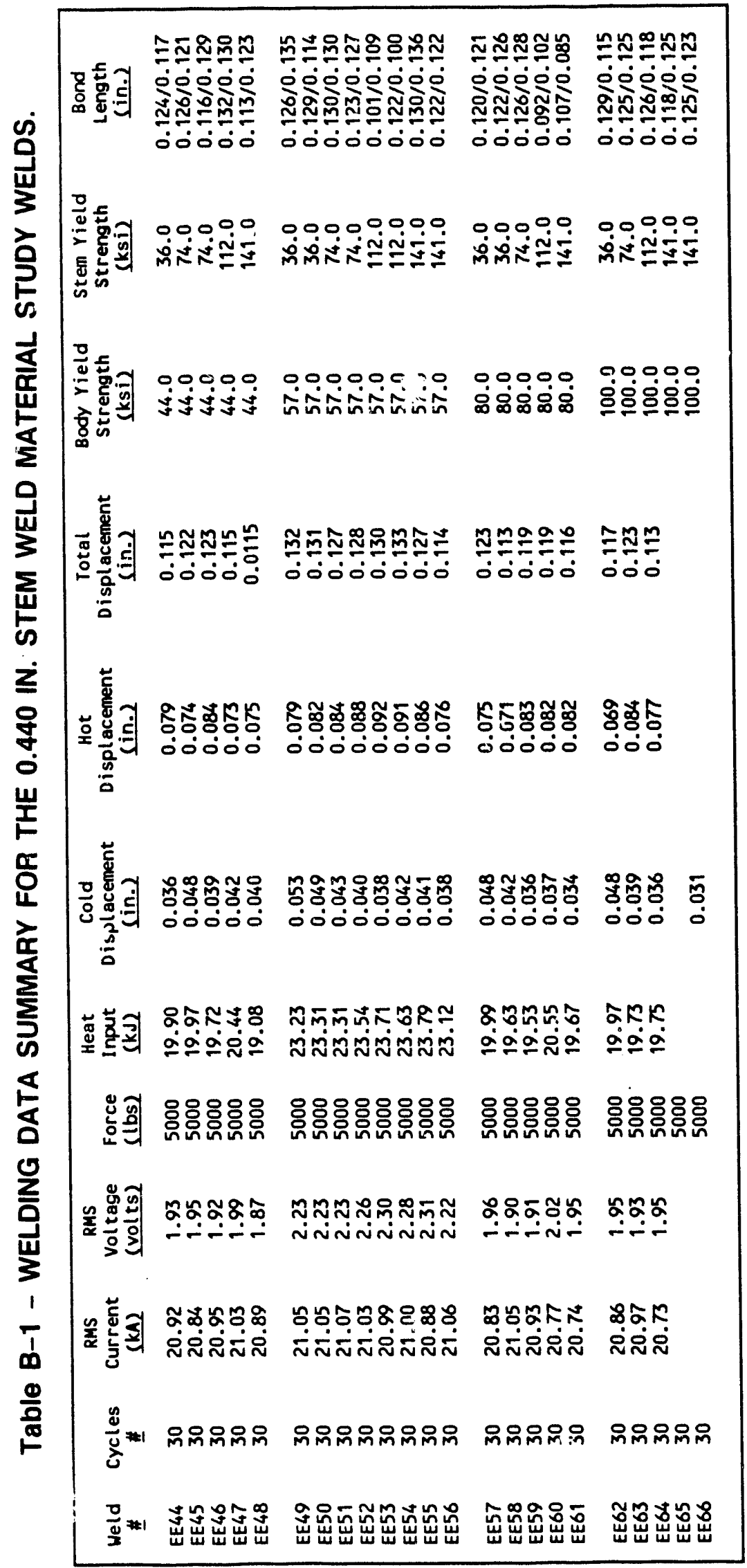




\section{Distribution}

\section{External}

OSTI UC-706 (118)

B. Eberhard. Westinghouse Savannah River Site

B. K. Davis, Los Alamos National Laboratory

K. Hicken, Sandia National Laboratories, Livermore

W. R. Kanne. Westinghouse Savannah River Site

D. M. Kasberg, Sandia National Laboratories, Livermore

J. A. Morley, DOE/DAO

R. W. Okagawa, Los Alamos National Laboratory

J. R. Spingarn, Sandia National Laboratories, Livermore

J. B. Straw, Los Alamos National Laboratory

D. Struckman, EG\&G Rocky Flats

L. N. Tallerico, Sandia National Laboratories, Livermore

\section{Internal}

L. D. Haws

E. K. Johnson

W. H. Jones

J. R. McDougal

D. E. Michel

R. G. Miller (10)

M. A. Perkins (10)

Library (10)

Publications 

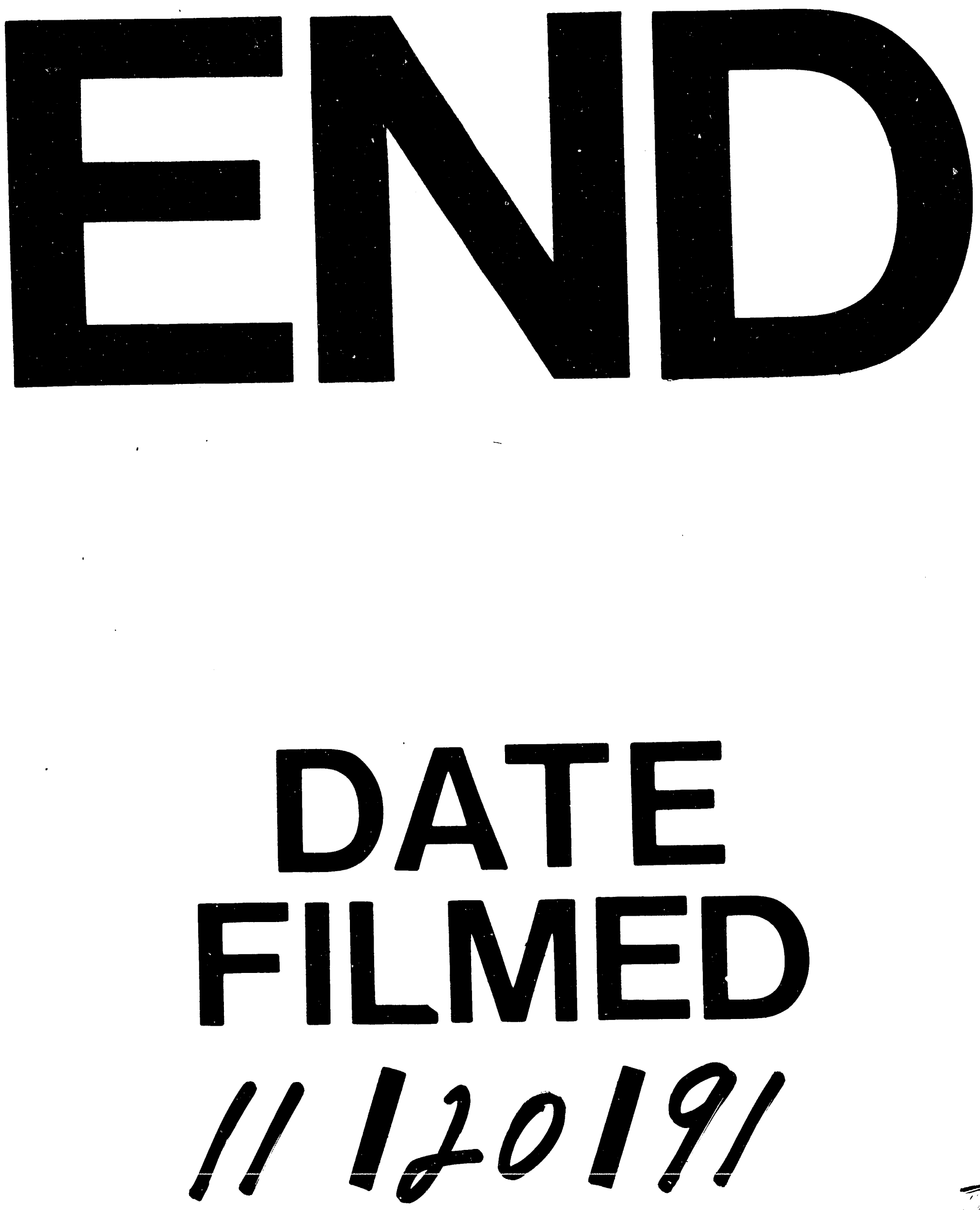

I 
- 